\title{
Michael N. Pearson: A Partnership Across the OCEANS
}

\author{
Teotónio R. de Souza ${ }^{\dagger}$
}

To cite this article: de Souza, Teotonio, R. "Michael N. Pearson: A Partnership Across the Oceans." Journal of Indian Ocean World Studies, 3 (2019), pp. 1-12.

More information about the Journal of Indian Ocean World Studies can be found at: jiows.mcgill.ca

(C) Teotonio R. de Souza. This is an Open Access article distributed under the terms of the Creative Commons License CC BY NC SA, which permits users to share, use, and remix the material provide they give proper attribution, the use is non-commercial, and any remixes/transformations of the work are shared under the same license as the original. 


\title{
Michael N. Pearson: A Partnership Across the OCEANS
}

\author{
Teotónio R. de Souza ${ }^{\star \dagger}$
}

Since my days of graduation in History I have not forgotten E.H. Carr's What is History and his advice that we should know the historian before we read his work, or something to that effect. ${ }^{1}$ My own entry into the field of History was via a Licenciate degree in Philosophy (Eastern and Indian) at the Jesuit run Jnana Deepa Vidyapith in Pune (India) in 1970, as a requirement of the Jesuit formation. It was concluded with the defence of an essay on "The structuralism of Claude LeviStrauss and his Interpretation of Culture" under the guidance of J. de Marneffe, S.J.

After an enviable performance and selection for a position as a professor at the institution, I was asked to proceed to Rome for a doctorate at the Gregorian University To the surprise of many I showed little interest in the offer, justifying this with my unhappiness about my crass ignorance of the historical contexts that had produced the philosophers and philosophies I had studied.

My religious superiors gave in and allowed me to enrol for a degree in History at the University of Poona, recently renamed Savitribai Phule Pune University. My high ranking in M.A. examinations won me a couple of University prizes, but more importantly a grant from the University Grants Commission (UGC) to pursue a doctorate in 1972. That set the stage for the start of my Ph.D. research at the archives in Goa, and my encounter with M.N. Pearson.

My journey through Philosophy and History would first require me to wade through yet another Jesuit requisite, a bachelor degree in Theology at the same Jnana Deepa Vidyapeeth (Pontifical Atheneum). It was completed successfully in 1979 following two years of class courses and the presentation of an essay entitled "Pilate before Jesus: a historico-theological reflection on Christian revelation" under the guidance of George Soares-Prabhu, S.J. In the above essay, I inverted the roles played by Pilate and Jesus, and described it as an historical event of unhappy memory, an event that decided the fate of Jesus and made it an important item of the Christian creed. The essay sought to review the historical vicissitudes of Christian revelation and the chequered understanding of its history. It took up the salvation-historical

\footnotetext{
$\dagger$ We regret the death of Professor Teotónio de Souza, who passed away in Lisbon on 20 February 2019.

* For further information regarding the author, please see: http://orcid.org/0000-0002-9397-1433.

1. E.H. Carr, What is History? (Cambridge: Cambridge University Press, 1961).
} 
interpretation of revelation for scrutiny in the light of modern historical criticism and interpretation. Pilate is recalled as presenting Jesus as Ecce Homo (Behold the Man) to the crowd that sought his condemnation. Pilate had conceded to scourging, but could find no fault for handing him the death penalty. Pilate was the judge, but sought an explanation from his victim when he asked Jesus: What is truth?

It is against this educational background and intellectual formation that I wish to present some snippets of my understanding of Ecce Homo, read M.N. Pearson. I doubt, as did Pilate, if I will betray the Man to save any chair. I shall not need either to wash my hands, nor hand over any victim to crucifixion. It is Mike (M.N. Pearson) who has provided insights in Appendix I (attached to this text) for understanding some misjudgements that plagued me and were witnessed by him.

I need only to add to this introduction that behind his big frame and beard which often hides his grin quite effectively, Mike rarely lets out his emotions. At most, one can at times hear a grunt if the conversation veers towards someone or something that touches a raw nerve.

I believe that presently Mike will benefit from his break from research and academic chores to reflect and cherish his human qualities and the contribution made

The Goan beginning of a life-long fellowship (1980)

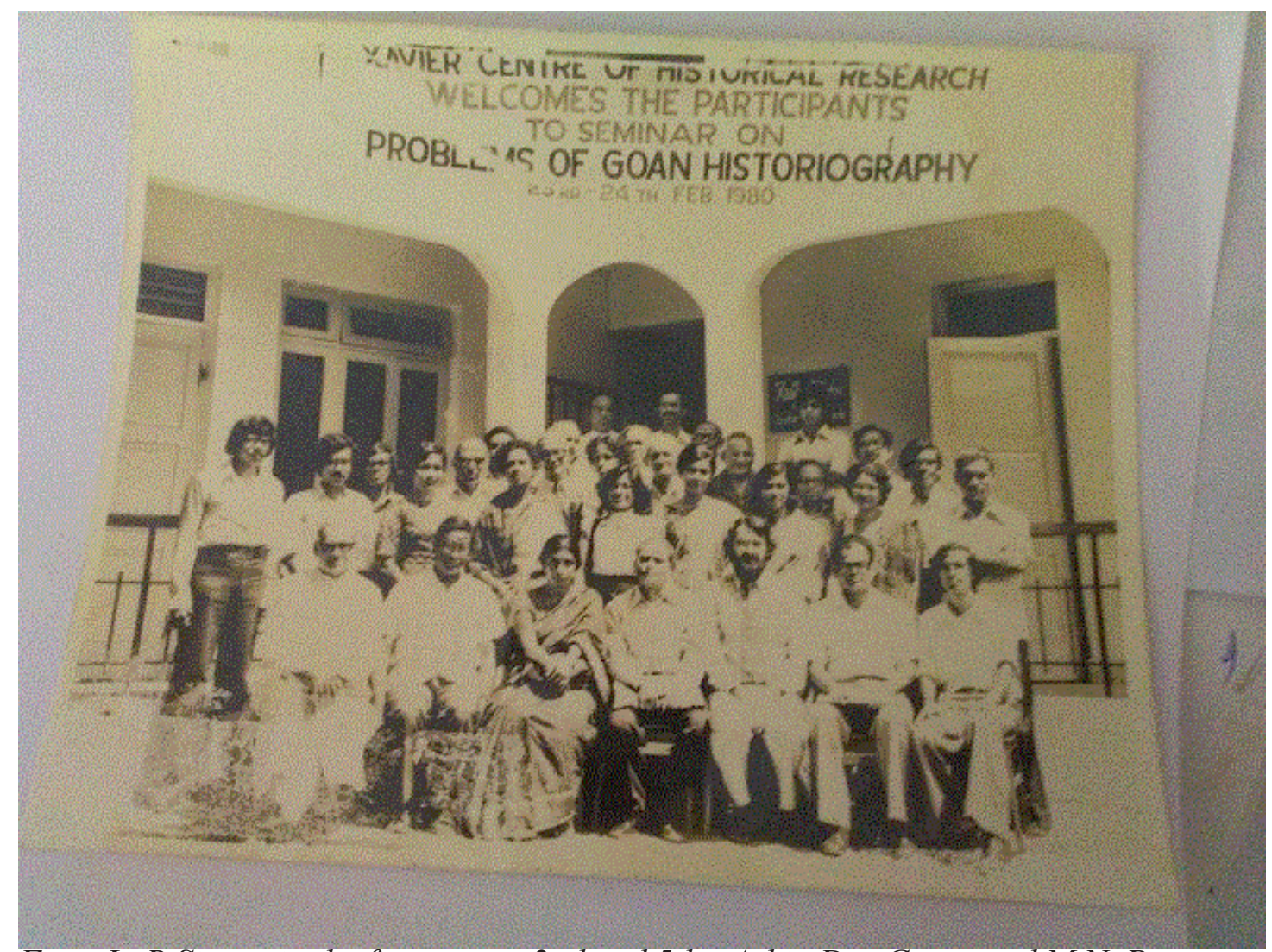

From L -R Sitting in the front row - 2nd and 5th - Ashin Das Gupta and M.N. Pearson 
to humanity. This includes the notable performance of his eldest son Ben, a senior Green Peace Campaigner, whom he mentioned often in our conversations. I am inclined to believe that Mike saw his son completing more visibly the human side of his interest in the Indian Ocean World.

$$
* * *
$$

Since his pioneering study Merchants and Rulers in Gujarat: The response to the Portuguese in the sixteenth century, M.N. Pearson has been a leading voice in Indian Ocean historiography. ${ }^{2}$ While I was still working on my Ph.D. thesis in the Goa archives, my attention was drawn to one of his articles published in the journal Mare Luso-Indicum. I was impressed by his incursion into a theme that was under my scrutiny at the time.

The article explored attempts by the Portuguese administration in India to collaborate with the local Hindu tax-collectors, despite legislation which favoured converts to Christianity, and the denial of many political, economic and social rights to local Hindu inhabitants. The author presented an estimate of the importance of the taxes ("rendas") for the total economy of the Portuguese Estado da Índia in the $17^{\text {th }}$ century. Out of 355 tax-farmers studied by him, $80 \%$ were Hindus, including $62.5 \%$ Saraswat Brahmins, who controlled nearly $60 \%$ of the total value of the taxes ${ }^{3}$, and maintained economic power to resist political pressures.

That is how and when our interaction began, particularly following my response to the above article in the journal of the Heras Institute (Mumbai). ${ }^{4}$ With more archival data at my disposal I was in a position to correct and finetune some of Pearson's conclusions. He seemed grateful for this, while I too benefitted immensely from his insights and clues. Only very recently I made reference of my gratitude in a conference at the University of Lisbon on "Rendas e Rendeiros na Administração da Fazenda na Índia Poruguesa"."

When I presented my doctoral research at the University of Poona (India) and prepared to launch the Xavier Centre of Historical Research in Goa in November 1979 , it was my privilege to interact more closely with M.N. Pearson and seek his collaboration. In the meantime, my doctoral thesis was approved and published as Medieval Goa. Among many accolades, it earned a critically positive appraisal by M.N. Pearson, who described the work as "typical of many young Goans who are

2. M.N. Pearson, Merchants and Rulers in Gujarat: The Response to the Portuguese in the Sixteenth Century (Berkeley: University of California Press, 1976).

3. M.N. Pearson, 'Indigenous dominance in a colonial economy: The Goa Rendas, 1600-1670', Mare Luso-Indicum, II Genève, (1973): pp. 61-73.

4. T.R., Souza, 'Glimpses of Hindu Dominance of Goan Economy in the 17th Century', Indica, 12:1 (1975): pp. 27- 35.

5. https://apatria.org/sociedade/rendas-e-rendeiros-na-administracao-da-fazenda-na-india-portuguesa/ 
strongly critical of many Portuguese policies in the colonial past, and who identify with Indian nationalism". Though somewhat unhappy with my marginal treatment of the maritime matters, he found a justification for it: "There seem to be two reasons for the author's concentration on the land. First, he wants to talk about the socioeconomic history of the common people, and they were mostly peasants little affected by nautical matters. Second, thanks to the Dutch, by early seventeenth century the Portuguese had lost much of their sea trade. Thus land matters were more important

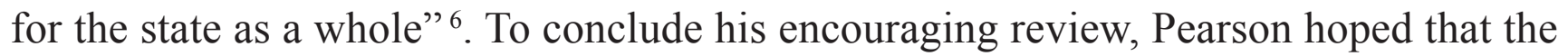
book would continue the ongoing renaissance of Goan and Indo-Portuguese studies.

In partial realization of his wishes, the Xavier Centre of Historical Research (XCHR), operating initially from provisional premises at Miramar, a coastal zone of Paniim, the capital city of Goa, and later in Porvorim, initiated a series of annual local seminars from 1980. M.N. Pearson, along with Ashin Das Gupta, Lotika Varadarajan, and other prominent local historians, guided young Goan researchers in the "Problems of Goan Historiography". Both M. N. Pearson and myself looked up to Ashin Das Gupta, a pioneering Indian maritime historian, as our guru. While Ashin Das Gupta took an interest in my work from the time he was a member of my Ph.D. examination board, both accompanied me during the years that followed as close collaborators and guides in the research activities of the Xavier Centre of Historical Research, egging me on to link the sea and the land in the research projects of the new Institute.

I remember Ashin Das Gupta telling the audience at the annual seminar in Goa, with his characteristic tongue-in-cheek humour, that whaling and fisheries were something esoteric for historians, and that he had little doubt that if Indian historians donned the diver's suit for underwater archaeology, not many would surface! M. N. Pearson, not so prone to black, grey or any known shade of humour, pressed convincingly for proper interdisciplinarity in maritime history, rather than a methodology consisting of a simple amalgam of disciplinary curiosities. Further arguing that the historian could not afford to stray too far from the samudra manthan (churning of the ocean) as a source of common sustenance, not just for coastal societies, but also those deeper in the hinterland.

At this Goa seminar M.N. Pearson presented a paper on "Goa in the early nineteenth century: Some British accounts". The proceedings did not get published, but I invited him to include it in a Festschrift volume that I jointly edited with A.R. Kulkarni and M.A. Nayeem in honour of Professor P.M. Joshi. Professor Joshi was the retired director of Maharashtra Historical Archives, and the historian who headed the Indian team that accompanied the case of the "Right of Passage" of Portugal v/s India at the International Court of Justice. He was also the chief guest for the inauguration

6. M.N., Pearson, 'Book Reviews', The Indian Economic and Social History Review, 27:3 (1980): pp. 343-344. 
of the XCHR and the release of my monograph, Medieval Goa on November 4, 1979. ${ }^{7}$

Pearson quoted the book of J.B. Amancio Gracias who had studied the documents listed earlier by J.A. Ismael Gracias, including the manuscripts from the British Museum Library, in his article in O Oriente Portuguez in 1907. But while these authors concentrated on political issues, Pearson called our attention to a detailed account of Goa in 1811-12 by a young British survey officer, Lt. James Garling, who used the art of triangulation, earlier applied in India by James Rennel and his successor surveyor-general in 1800, William Lambton.

\section{$* * *$}

Pearson traced Girling's background from his birth in London in 1784, through his drafting into the cadets in 1803, his progression to Lieutenant of the 11th Regiment in 1804, and his graduation as a surveyor from the Madras Military Institution in April 1805. He then served as surveyor in Bombay during 180809 and later returned to Madras. He travelled across India, including Goa, with his surveying team in 1810. Garling would then die of cholera in Nizam's Hyderabad as Brevet Captain in 1820, at the early age of 36. His survey of Goa was completed in 1813 and included in the official trigonometrical survey of India.

A descriptive memoir in the survey volume distinguished Old and New Conquests, and covered rivers and provinces, with summaries of productions, resources, trade, population, revenues, military force and ecclesiastical establishment of the territory, account of the inhabitants and their customs and education. Part III (fls 201-312v) included varied information, including a general account of the roads (fls. 2012-220) and routes through the Portuguese territories of Goa, including the Suttur Jaghir and a memoir on the same (fls.221312), an independent Maratha chiefdom, on the east and north of Goa, covering 203 square miles with 82 villages, never subject to direct Portuguese rule. Another copy of Part III of Girling's account is found in the British Library with a colour map at a scale of 4 miles to the inch. It is less detailed but easier to read.

Pearson traced the rare map that accompanied the description in the India Office Library in London to three versions dated between 1818 and 1827, drawn at a scale of 2 miles to 1 inch, on sheets measuring 30 inches by 39 inches. Hence the final version was produced by the Surveyor-General Office in Madras several years after Garling's death. Curiously the churches are distinguished by a red cross on the buildings. The published original in Phillimore's Survey of India is dated Fort St George 29 May 1814. Pearson compares this British map with other

7. M.N. Pearson, "Goa in the Early Nineteenth Century - Some British Accounts", in A.R. Kulkarni, M.A. Nayeem and T.R. de Souza (eds), Mediaeval Deccan History, (Bombay: Popular Prakashan Pvt. Ltd, 1996): pp. $229-236$. 
near contemporary French and Portuguese maps of Goa. Pearson's advice to Goan scholars was to follow up Garling's description of Goa with contemporary political, economic and social details for a detailed micro-study of Goa around 1800. Pearson also pointed to a volume in the British Library, entitled "Marquis Wellesley, Correspondence relative to Goa". Although Napoleon was stopped in Egypt by the middle of 1799, the British seemed worried by the agreement of 1801 between Portugal and France, which gave to the French considerable influence over Portuguese colonies. Wellesley instructed William Clarke in Goa through a letter on January 17, 1892 to take over the Portuguese administration. However he replied that he preferred to not do it yet, and enclosed detailed information he had collected locally about the administrative, ecclesiastical and revenue set-up and which could be useful for a decision to take over the Portuguese territory in future. Pearson drew our attention to fls 35-37 on "Communications with the Coast through Goa and Soonda",

From all the above information provided by M.N. Pearson nearly 40 years ago we can conclude that the British survey of Goa continued to serve them well when handling mutinies in Kolhapur and Sawantvadi (1837-44) half a century later. This was also prior to the better known Sepoy Mutiny of 1857, when the Portuguese jurisdiction of Goa and its border areas were infiltrated by some of the mutineers. In this case, the British authorities had pretty accurate information about the localities where they found shelter in Goa. Again, the maps and earlier studies may have been of much help. John Elphinstone, the governor of Bombay during the Mutiny, sought Portuguese assistance to track and hand-over or deport to Timor many of those whom the Portuguese decided to regard as refugees who deserved its sovereign protection.

Following on from that seminar, M. N. Pearson was generous to let the XCHR publish his Coastal Western India (1981), which continued the XCHR Studies series inaugurated with C.R. Boxer's João de Barros: Portuguese Humanist and Historian of Asia. The Coastal Western India preceded the The Black Legend of Portuguese India : Diogo do Couto, His Contemporaries, and the Soldado Prático (1985) by another stalwart of Portuguese historiography, the late George D. Winius, whom I owe much gratitude for his life-long support and encouragement. Coastal Western India was released by André Gonçalves Pereira, the Foreign Minister of Portugal in the post-Salazar government, during his visit to Goa, his land of origin. Of particular interest were the two first chapters dealing with the "The Goa Archives and Indian History", and with "Corruption and Corsairs in Sixteenth-Century Indian Oceans: A functional analysis", but all the essays in the book were a breath of fresh air for young Indian researchers.

The XCHR grew from strength to strength during the first decade and half of its existence, until I decided to leave the rudder and shift my base to Lisbon in 1994. Following the inauguration of the permanent premises of the XCHR in Porvorim (Goa) on the occasion of the first International 
Seminar of Indo-Portuguese History (ISIPH), XHCR organized the third and the seventh seminars of the series in Goa, in 1983 and 1994. Pearson was visibly absent from several of these seminars, but not without presenting his understanding of a maritime history at ISIPH-2 held in Lisbon in $1980 .^{8}$

Among several seminal concepts that Pearson fine-tuned and illustrated better in his later writings, his presentation in Lisbon Pearson defended the relation between land and sea as symbiotic, but asymmetric, showing how most often the sea had less influence on the land than vice versa. Pearson also sought to delink many European perceptions of maritime history and pointed out serious flaws which disqualified them from being fully applicable to the Indian Ocean which in particular had its own characteristics regarding boundaries. He introduced the idea of continuum, borrowed from urban history and "rurban" zones as applicable to connect the littoral and the hinterland. He also touches on another issue that he presented as a core problem, namely the co-opting of maritime history as a part of imperial history.

$* * *$

It may not be politically correct for me to say that Pearson's method of ordering from the methodological menus of maritime history and the history of the Indian Ocean in an à la carte style cost him ideological resistance, which meant a degree of alienation from certain types of historians and some sources of funding. I hope that I am not invading any private arena or violating any forum of privacy if I disclose that M.N. Pearson confided in me once that he felt ignored at certain events of his preferential academic interest. It is a price many of us have to pay for placing our research findings above the politics of careerism and the whimsical interests of potential funders.

Due to a serious health problem in 1982, I could not respond to Pearson's kind invitation to contribute to his edited volume on the Indian Ocean, a veritable charter of his life-long production, duly acknowledged as such by Lakshmi Subramaniam in her introduction to the first of this two volume Festchrift by the Journal of Indian Ocean Studies (JIOWS). ${ }^{9}$ Despite a recurring health crisis and heart surgery, I could muster sufficient grit to put together some fresh documentation (much of which will need to find another opportunity for publication) which I had gathered recently in the Goa archives and elsewhere, and join friends and well-wishers of M.N. Pearson to present this introduction to the second volume of JIOWS as my personal

8. M.N. Pearson, 'The Indian Ocean and the Portuguese in the Sixteenth Century', editor? II Seminário Internacional de História Indo-Portuguesa (Lisboa: Instituto de Investigação Científica Tropical, 1985), pp. 103-117.

9. Lakshmi Subramanian, 'Introduction: The Ocean and the Historian', Journal of Indian Ocean World Studies, 2:1 (2018): pp. 1-11. 
homage to "Mike", a giallo, as the late Umberto Eco would call it (translation). Though I prefer a jhello in Konkani (translation), my Goan mother-tongue. While Ashin Das Gupta took fancy for the peddling merchant, though modifying the original understanding provided by van Leur, ${ }^{10}$ M.N. Pearson has familiarized us with the Hajj market, the Swahili people, and much beyond the Gujarat case (which Sanjay Subrahmanyam later used to sideline Pearson's analysis and offer his model of "Connected History" a far cry from a more demanding convergent research).

Pearson's The Portuguese in Gujarat should be mentioned alongside several of his later writings, including his Pilgrimage to Mecca: The Indian Experience 1500-1800. ${ }^{11}$ His vision of the sea as a connector, rather than divider, could be considered a more appealing tool to work on a Connected History. While one should also greatly appreciate M.N. Pearson's quality to withdraw and repent when he sensed that he may have erred. In other places, rather than limiting the evaluations of colonialism through terms such as banditry and capitalism, or to some other variants of a "binary logic" from a bifurcated viewpoint, ${ }^{12}$ M.N. Pearson helps to understand better the Anglo-Dutch stereotypes of pre-capitalist structures of the Portuguese imperialism and its anti-Muslim obsession. This in many ways is just like Ashin Das Gupta who suggested that the migrations of Konkanis from their original homeland need not be attributed to the Portuguese violent conversion and inquisition policies, but could be the result, very ironically, of their policies which disrupted the Muslim monopolistic grip over trade in Malabar and created new opportunities for the Hindu Konkani merchants. In the long run, it is the example of Ashin Das Gupta and M.N. Pearson's balancing micro and macro approaches, reflecting the calm of oceanic depths rather than its agitated surface, from which history and the public have much more to gain.

Though my contact with M.N. Pearson became sporadic after my shift from Goa to Lisbon in 1994, our academic links and mutual concerns remained undiluted. When I was invited to help in the planning and organization of the International Conference, hosted to mark 500 years of the voyage of Vasco da Gama to India, I was given the privilege of drawing up the list of scholars to participate in the event. I could not fail to include my dear old friends, Ashin Das Gupta and M.N. Pearson. With the last-minute absence of Ashin Das Gupta due his failing health, I had the privilege of reading out his paper at Sorbonne (Paris). Both papers, namely "The Vasco da Gama Epoch" (pp. 23-31)" by

10. I. Habib, "Reading Ashin Dasgupta", in Ashin Das Gupta (ed.), India and the the Indian Ocean World: Trade and Politics (New Delhi: Oxford University Press, 2003): pp. xxv-xxvi.

11. M.N. Pearson, Pilgramage to Mecca: The Indian Experience, 1500-1800 (Princeton: Marcus Wiener Publishers, 1996). 12. S. Subrahmanyam, The Portuguese Empire in Asia, 1500-1700, (London: Longman Group, 1993). 
Ashin Das Gupta, and "Portuguese India and the Mughals" (pp. 223-236) by M.N. Pearson, can be found in the first volume of the published proceedings. ${ }^{13}$ Pearson compared and analysed the Portuguese and the Mughals who arrived in India within three decades of each other. While the Portuguese aspired for thalassocracy in the Indian Ocean, the Mughals organized themselves into a classic tributary empire. Both interacted in ways to protect and promote individual interests at official and private levels, making concessions and seeking adjustments to avoid conflicts, especially after the Mughals extended their control to littoral Gujarat and littoral Bengal. Pearson did not fail to point out that while the Mughals chose to make India their home, the Portuguese always looked towards their distant metropolis. Additionally, while the Mughals integrated Hindus at all levels and ranks of their administration, that was never the case with the Portuguese. ${ }^{14}$

Pearson did not shy away during the gathering of world scholars at the Sorbonne from stating that it would be a mistake to see the arrival of the Portuguese in India as marking a new era in the Asian history, or to see Vasco da Gama beginning a phase of European domination of India. Pearson did not forget to cite Sanjay Subrahmanyam in reference to a common millenarian trend in the West and the Islamic thought in the sixteenth century, and went on to anticipate the validity and usefulness of a search for connections and commonalities in the early modern world as a fruitful approach, without yet baptizing it as "Connected History." 15

It gave me a renewed satisfaction to be honoured with a Festschrift entitled Metahistory: History Questioning History (Lisboa: Nova Vega, 2007) to mark my 60th birthday, edited jointly by Charles J. Borges, who shared my burdens at the XCHR in Goa for nearly 15 years, and my friend M.N. Pearson. Mike was unable to be present for the release of the Festschrift, but in addition to an essay on "East Africa and Indian Ocean World" 16 sent a brief and touching personal message dated March 18, 2007 from Lennox Head. Therein he summed up very frankly his memories, feelings and impressions about our long academic journey together. ${ }^{17}$

As I mentioned earlier, Pearson remains ever open, as any good researcher should, to revising his earlier conclusions whenever new evidence or a better grasp of the sources demand it. Pearson's essay in Metahistory bears testimony to this when he writes: "My own earlier foray into African history strongly favoured the 'Swahili are African' notion. However, further reflection, and some recent publications, have led me to modify this stance substantially. I will argue that in fact the Swahili were oriented much more strongly to the Indian Ocean than to the interior - in geographical

13. Vasco da Gama e a Índia, 3 vols. (Lisboa: Fundação Casloute Gulenkian, 1999).

14. Ibid., vol.I, p. 225.

15. Ibid., p. 224.

16. C.J. Borges \& M.N. Pearson, Metahistory: History Questioning History, (Lisboa: Vega, 2007): pp. 485-508).

17. See Appendix.I. 
terms to their foreland rather than their hinterland." Pearson leaves a challenge: "Let me emphasize at one that if these findings are unacceptable to some scholars, then they are welcome to present counter-arguments." A little later, he confessed: "I railed against them in my earlier work, but have now been converted." With no qualms about referring to flaws in his own work, he courageously concluded that "while the Indian Ocean network has operated to spread, and then influence, Islam on the coast, there has been little flow the other way, from the coast to the wider Muslim world" In essence, that Africa did not produce its own Mecca, Medina, Deoband or al Azhar.

To conclude, I need to thank the editorial board of JIOWS for providing me this rare opportunity of sharing with the friends and admirers of Michael N. Pearson, as well as the wider public interested in Indian Ocean Studies or maritime history in general, some milestones that marked a fellowship that started in Goa in 1980 and seems to have come to a "provisional" stop, but hoping that it only means: Stop and proceed ! In my eager response to Mike's appeal we crowned Orta's Colloquies at the Calouste Gulbenkian Foundation in Lisbon (where M.N. Pearson presented a keynote address) with our celebration of friendship with Goan food at the Sabores de Goa, a restaurant in Lisbon, on April 13, 2013. ${ }^{18}$

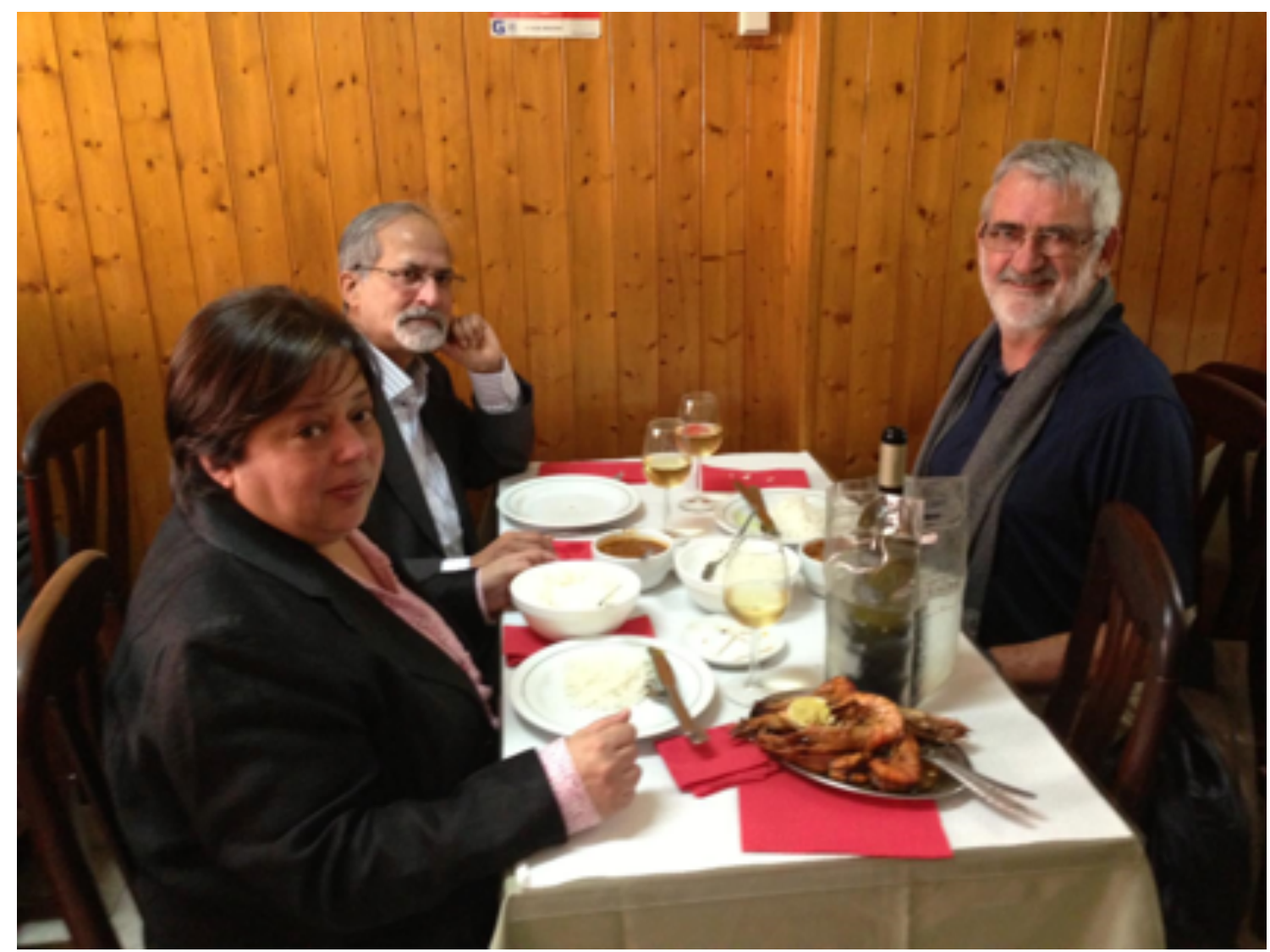

Mike at Sabores de Goa (Lisboa) with my wife Elvira and me [13 April, 2013] 


\section{Appendix I}

I very much regret that I am unable to be with you today to celebrate the life [so far] and times of my dear friend Teotonio, and to be with you all to welcome the publication of Metahistory.

Teo and I go back a long way indeed, to a time when he was still training to be a Jesuit and I was on my first marriage. Over the years we have met in Goa, at the Xavier Centre, very many times, and also at various conferences and meetings. One of the most lavish was the one he organised in Paris for the anniversary of Vasco da Gama. It was notable at this conference that scholars of all persuasions and political sympathies were invited and attended. This says much for Teo's tolerance, for some of those present had treated him scandalously in the recent past. Indeed, as several contributors to Metahistory have noticed, our guest of honour has several times been subjected to much more negativity and back biting than he deserves.

Teo wears his heart on his sleeve, and this also has got him into trouble at times! He is broadly sympathetic to the subaltern and the dispossessed. This has caused him to criticise the Portuguese colonial effort, and his own Jesuit order, from time to time. It's true that his politics are not far from my own, but even leaving this aside I think he needs to be congratulated for taking a stance, and for writing history which does allocate praise and blame where this is appropriate. This is much more honest than the work of scholars who abdicate all responsibility to evaluate the actions of people in the past: I will refrain from giving examples!

A notable feature of Metahistory is pages 15 to 26, where Teo's vast list of publications are set out. They represent an amazing contribution from such a young [ish] scholar, one who certainly will have many more things to say and write yet.

I would like to thank all the contributors for their valuable chapters. It is a sign of the respect in which we all hold Teo that we have all tried to write chapters of a quality which will we hope match his own high standards. As co-editor I owe an especial debt to another old friend, Charles Borges, who did nearly all the work involved in coordinating this project, though Teo himself helped actively in this enterprise, particularly in finding the publishers and accompanying the vital phase of proofreading and indexing. I hope he will recognise that this handsome volume testifies to the esteem and affection in which we all hold him.

Michael Pearson

Lennox Head

March 18, 2007 


\section{Appendix II}

14/02/2013, às 23:19, "Michael Pearson"<mnpearson@,ozemail.com.au>

Dear Teo: it's ages since we were in touch. I do hope all is well with you and Elvira. I have enjoyed reading your articles on the www.academia.edu site; it's a good way to find out what you have been doing. I've been travelling a lot: in India three times last year, and most recently in Uruguay, where our son married a local girl.

BUT I will be in Lisbon in April ! I am speaking at a conference on the 450 anniversary of Orta's Colloquios. The meeting is April 10 to 12, and then I will be in Portugal for a few more days, before going off to Canada for another conference at McGill University.

Can we meet? I would love to see you !

Do let me know.

Warm wishes

Mike 